[Original Article]

Received April 25, 2017

Revised July 11, 2017

Accepted July 17, 2017

${ }^{\dagger}$ Corresponding author

(elee@kookmin.ac.kr)

ORCID

kim hae yeon

http://orcid.org/0000-0002-9456-8566

Park Sun-Kyung

http://orcid.org/0000-0001-9046-2177

Eun-Jung Lee

http://orcid.org/0000-0002-9005-5886

This paper is in part supported by the faculty research fund of Kookmin University.

\section{Modernistic reinterpretation of stage costumes in the opera 〈La Serva Pardrona〉 \\ - Focusing on the decorative elements of the Rococo mode -}

Hae-Yeon Kim, Sun-Kyung Park and Eun-Jung Lee ${ }^{\dagger}$

Dept. of Fashion Design, College of Design, Kookmin University, Korea

\section{오페라〈La Serva Padrona〉 무대의상의 현대적 재해석 \\ - 로코코시대의 장식요소를 중심으로 -}

\author{
김해연 · 박선경 · 이은정 ${ }^{\dagger}$ \\ 국민대학교 패션디자인학과
}

\begin{abstract}
Opera is the most comprehensive musical art. In recent years, contemporary opera worlds has seen a variety of attempts to reinterpret operas of the past in a modern light. This has resulted in a dramatic change in the production of musical style and stage art. The purpose of the study was to modernize and streamline opera costumes by extending the scope of existing stage costume design, through the reinterpretation and application of the decorative elements in the Middle Age of Rococo, such as ruffles, frills, shirring, embroidery, buttons, etc., in such a way as to effectively communicate the moods of an opera to a modern audience. The costumes of the Rococo period were reinterpreted in a modern way, with the following results. First, in this work, the male main character was played by a bass to express the image of an older, lazy, rich man. A key element in modernizing the stage costume was selection of the costume color in such a way as to visually represent the voice tones sung by the major characters in the opera. Second, the maid hat and aprons were decorated with frills by applying the curves of Rocaille decoration from the Rococo period symbolize the role of the maids. This represented the distinction between occupation according to class and status at that time, while also expressing the ideals of modern feminine beauty. This makes for more comfortably-worn costumes, and is economical for production expenses. In the future, the stage costume design for classical opera will need to be revised consideration of a modern viewpoint.
\end{abstract}

Keywords: opera buffa(희극오페라), pergolesi(페르골레지), La Serva Padrona(마님이 된 하녀), Rococo(로코코)

\section{Introduction}

국내 현대인의 삶에서 공연예술은 중요한 문화생활활동의 하나로 자리 잡게 되 
었다. 이는 주 5 일 근무 및 대체휴일제 등에 의한 여 가시간 증가, 교육수준의 향상에 따른 삶의 질과 정 신적 만족 추구의 라이프스타일, 다양한 미디어를 통 한 해외 문화 트렌드의 실시간 보급 등에 기인한다. 한편, 공연예술분야 중 오페라(opera)는 특유의 고전 주의 음악과 초기 제작 당시의 왕정 및 부르주아적 취향에 기반한 극적 흐름 등 형식적 고유성에 의해 현대에도 그 관객층이 특정 매니아 층에 한정되어 왔 다(Byun, 2005). 반면, 뮤지컬(musical)은 현대적 줄 거리와 음악, 화려한 볼거리 등으로 폭넓은 관객층을 확보하고 있다. 현대의 한정된 오페라의 형식성과 제 한적인 관객층은 결국 관련 시장 자체의 축소라는 부 정적 효과를 낳으며 문제가 되고 있으며, 이에 고전 오페라 형식의 현대화를 통한 대중성 강화와 관객층 확장을 목표로 한 새로운 시도들이 이루어지고 있다 (Byun, 2005; Yoo, 2011).

가령 2005년 짤스부르크 페스티벌(Salzburg Festival)에서 무대연출자 빌리 데커(Billy Dankert)는 오페 라 “라 트라비아타(La Traviata)"를 재해석한 혁신적 공연을 선보여 큰 화제가 되었는데, 그는 핵심적 공 연 요소들에서는 전통성을 유지하면서도, 단순화된 무대연출에 현대적이고 상징적인 무대의상을 선보여, 고전 오페라 현대화의 성공적 사례를 남겼다(Yoo, 2011). 당시 해당 공연의 실황을 담은 DVD는 장기간 베스트셀러 목록에 올랐고, 빌리 데커(Billy Dankert) 는 이 공연을 통해 연출자로서 국제적인 입지를 형성 했고, 비올레타(Violeta) 역을 맡았던 안나 네트렙코 (Anna Netrebko)는 이 작품을 계기로 대중적 인기를 얻으며, 다양한 패션과 광고 분야의 아이콘이 되었다 (Yoo, 2011). 무엇보다 이 공연은 오페라 연출 및 무 대구성의 변화를 통한 고전 오페라의 성공적 현대화 가능성의 한 방향을 제시했고, 그 과정에서의 연관된 무대의상 등 오페라의 핵심적 구성 요소들의 중요성 에 대한 인식을 심어주는 계기가 되었다. 국내에서도 오페라의 현대화는 다각적으로 이루어지고 있다. 가 령 90년대 이후 우리나라의 전통 컨텐츠를 바탕으로 한 창작오페라들이 제작되기 시작하여 2000년부터 본격적으로 심청전이나 이순신, 선비, 명성왕후 같은 작품들이 봇물처럼 쏟아져 나왔다(Kim, 2005). 또한 최근 국내에서 초연된 현대적 버전의 오페라들은 음 악적 양식과 무대미술의 연출방법이 크게 변화하면
서 오페라 및 뮤지컬 등의 원조를 표방하는 외국 오 리지널 팀의 국내 내한 공연이 증가하고 있는 반면, 국내 배우와 가수들이 출연할지라도 무대와 의상들 은 오리지널 팀의 것들을 수용해야 하는 등 라이선스 공연도 많아지고 있다(Yoo, 2013). 이처럼 고전 오페 라의 현대적 재해석 또는 고전 문화 컨텐츠를 새롭게 오페라로 제작하는 등의 오페라 시장의 다각화 추세 에 맞추어 제반 무대공연요소들의 현대화 또한 이슈 가 된다. 특히 오페라의 현대화는 제반적인 무대의 구성요소를 어떻게 조율하고 변화시키는가가 중요하 다. 즉, 오페라는 같은 작품일지라도 어떤 성악가가 노래하고 연기하느냐에 따라 재미나 감동이 달라질 수 있으며, 전통적인 방식으로 연출하느냐, 무대를 현 대로 옮겨 작품을 새롭게 해석하느냐에 따라 감상하 는 느낌이 달라질 수 있으며, 이에 맞는 무대의상 디 자인의 개발 또한 매우 중요한 문제이다.

이처럼 급격히 변화되는 오페라 공연의 추이와 관 객의 수요에 부합하여, 오페라 무대의상의 디자인에 대한 학술적 연구의 필요성이 증가하고 있다. 기존 오페라 및 관련 무대의상에 관련한 국내 문헌은 무대 의상 비교분석(Kang, 2005; Yoo, 2011), 현대적 무대 의상 디자인연구(Choi, 2007; Kim, 2002; Yoo, 2013) 및 실물의상 제작(Kim, 2002; Lee, 2007) 등이 있었 다. 보다 구체적으로는 특정 오페라의 주연인물의 공 연의상들을 분석하여 새로운 디자인을 제안하거나, 고 전 오페라를 현대화시키는 등의 몇 편의 연구들이 진 행되어 왔다. 즉, Lee(2004)는 오페라 '토스카(Tosca)' 의 여러 공연 사례들을 분석하여 주인공 토스카의 의 상 디자인을 제안하였고, Choi(2007)는 오페라 '투란 도트(Turandot)'를 소재로 하여 각 공연마다의 특성 및 등장인물 별 특성을 고찰하였다. 한편, 고전 오페 라를 현대화시킨 논문으로 $\operatorname{Kim}(2002)$ 은 오페라 '라 트라비아타(La Traviata)'와 '토스카'에 등장하는 여 주인공의 극중 성격과 심리, 그리고 극의 분위기를 상징적으로 표현함으로써 오페라 의상의 현대화를 위 한 발전 방안을 제안했고, Byun(2005)은 오페라 '파 우스트(Faust)'를 현대적 감각으로 재해석하여 이에 맞게 주연인물, 주변인물, 기타 등장인물들의 극중 성 격과 극의 분위기를 상징적으로 표현한 현대적 디자 인을 제시하였다. 이러한 오페라 무대의상에 대한 기 존의 연구는 관련 연구가 거의 없는 상황에서 큰 시 
사점을 가지지만, 한편으로는 주로 잘 알려진 대표적 인 몇 개의 해외 작품에 집중되면서 제한적 연구 범 위라는 한계를 내포한다. 최근 보다 다각화되어 가는 국내의 오페라 공연 트렌드와 대중의 문화예술적 취 향의 발전에 미루어 볼 때, 이러한 오페라 무대의상 의 현대화에 대한 연구 범위는 보다 다양한 오페라 분야로 확대되어야 한다.

따라서 본 연구에서는 희극 오페라의 효시이면서 최근 국내에서 꾸준히 현대화되어 재공연이 이루어 지고 있는 작곡가 페르골레지(Pergolesi)의 '마님이 된 하녀(La Serva Padrona)'의 오페라 무대의상 현대화 를 연구한다. 이를 위해 2015년 11월 국내 공연의 무 대의상의 기획과 제작에 본 연구자가 국내 제작진과 공연 기획 단계부터 연출가의 연출 컨셉에 따라 무대 의상 디자인에 직접 참여하여 제작함으로써 무대의 상에 대한 실제 제작 프로세스와 구체적인 제작방법 을 요약했다. 본 연구의 결과는 실무적으로 의상 예 산비의 경제적 효율성과 다양한 표현을 요구하는 관객 들의 요구를 충족시킴으로써 오페라 공연의 활성화에 기여하고 간소화되는 무대장치와 오페라에 대한 대 중들의 관심 증대를 위해 국내 오페라의 발전에 기여 할 수 있다. 한편, 학문적으로는 기존 오페라 무대 의 상에 관련한 연구 흐름을 확장하여 무대의상의 시대 적 간격을 좁히고, 작품에 대한 이해를 바탕으로 한 무대의상 현대화, 그리고 이를 통한 오페라의 현대화 를 위한 현실적 아이디어 수립에 기여하고자 한다.

연구방법으로는 페르골레지(1710 1736)가 활동한 18세기 오페라 부파(Opera Buffa)의 특징과 'La Serva Padrona(마님이 된 하녀)' 작품배경에 대해서는 문 헌연구 및 이론적 고찰을 통해 조사하였다. 당시 로 코코(Rococo)시대 의상의 복식 연구 고찰 방법에 있 어서는 역사서를 비롯하여 미술서에 이르는 서적, 선 행논문, 해외사이트 등을 참고로 하여 살펴보았으며, 'La Serva Padrona(마님이 된 하녀)'가 공연되어온 유 투브 시각자료 사례들을 국외와 국내로 나누어 비교 및 분석하여 현대적으로 표현할 수 있는 방법을 모색 하였다. 본 연구의 범위로는 페르골레지(Pergolesi)가 'La Serva Padrona(마님이 된 하녀)'를 작곡한 시기가 1731년대였기에 루이 15세가 통치한 친정시기였던 1723년부터 1774년 로코코 중기까지로 연구의 범위 시기를 한정하였고, 작곡가인 페르골레지의 작품 세
계관과 작품의 의도를 무대의상에 반영하기 위해 18 세기 중기를 배경으로 복식 전반에 사용되었던 가장 대표적인 장식요소들의 형태 및 특징들을 도출하여 현대의 오페라 공연의상에 적용되는 과정을 제시하 였다.

\section{Background}

\section{Importance of <La Serva Padrona $>$ in opera} buffa

오페라 작품들은 16 세기 말 바로크 시대 이탈리아 의 피렌체 지방에서 귀족 계급의 예술로 발달되어 궁 정의 사교적 오락을 위한 것이 그 주된 목적이었다. 시 대적인 배경으로 보면, 르네상스 말기 이래 거의 중 단 없이 지속되어오던 궁정귀족 예술이 18 세기에 들 어오면서 정체 상태에 이르렀고, 대신 계몽주의와 공 리주의를 중심으로 한 인본주의 사상이 전파되고, 산 업사회로 발전되는 과정에서 다수 중산층이 영향력 있는 위치로 발돋움하기 시작했다. 귀족의 권위주의 나 특권에 대하여 개인의 자유 평등을 지향함으로써 문학, 예술, 철학 등 모든 분야에 걸쳐 대중화가 이루 어진다. 이러한 배경 하에 탄생한 것이 희극 오페라였 다(Heo, 1999).

18세기에는 음악이 장중하고 엄숙한 내용의 오페 라 세리아(Opera Seria)가 공연되어졌는데 $(\mathrm{Li}, 2012)$ 오페라 세리아가 무대에 올려지는 동안 막간의 기분 전환을 위해 소규모의 막간 음악극(intermezzo)으로 상연되어지던 것이 오페라 부파(opera buffa)이다. 오 페라 부파(opera buffa)는 서민들의 생활, 인정, 미담, 연애사건 같은 흔히 주위에서 접할 수 있는 친숙한 소재를 사용하여 귀족들의 생활을 꼬집기도 하고, 풍 자하기도 하여 인간의 약점들을 의인화했으며, 음악 은 가볍고, 가사는 자연스러워서 청중에게 즐거움을 줄 수 있었다. 오페라 부파가 대중들에게 호응을 받게 된 까닭은 오페라 세리아에서 느껴지는 압도적이고 작위적인 감정보다 인간적인 감정을 자연스럽고 활 기차게 표현하고 있는 점이 대중들에게 친밀하였기 때문이었다(Hur, 2009).

18세기 후반 서구의 귀족중심 사회에서 시민 사회 로 전환되는 과정에서 보잘 것 없이 막간극으로 시작 되었던 오페라 부파는 1760 년이 지나면서 하층계급 
의 오락물에서 다양한 종류의 중간계층의 희극으로 점차 중요성이 커져갔는데, 그 대표적인 작품이 바로 ‘La Serva Padrona(마님이 된 하녀)'라고 할 수 있다 (Li, 2012).

'La Serva Padrona(마님이 된 하녀)' 작품은 페르 골레지에 의해 1731 년에 작곡되었는데, 그 시대에 매 우 독창적인 작곡가로 평가되고 있으며, 단순하면서 도 가사에 맞추어진 선율의 변화를 통하여 인물과 감 정에 대한 묘사는 관중들에게 대단한 호응을 얻어서 막간극이 아닌 독자적인 형식으로 따로 분리되어 공 연되어진다(Yang, 1984). 이 작품의 발표는 당시 사 회 관습적으로 보았을 때 일종의 모험이라고 할 수 있었으나, 줄거리와 음악이 모두 풍자적이면서 쾌활 하고 기지에 넘치는 신선함으로 인해 불후의 명작을 낳은 작곡가라고 불릴 만큼 역사적, 예술적으로 비상 한 관심을 끌어온 작품이다(Heo, 1999). 페르골레지 는 26세에 요절하였기 때문에 그다지 많은 작품을 남 기지는 않았지만, 'La Serva Padrona(마님이 된 하녀)' 작품은 오페라 장르에 큰 영향을 파급시킨 작품으로 희극 오페라의 위치를 확고히 하게 되면서 오늘날까 지 우리에게 전해지고 있다( $\mathrm{Li}, 2012)$.

\section{Historical background of Rococo costumes}

18세기 로코코 시대는 세 시기로 구분되어지는데, 초 기는 어린 루이 15세 대신 숙부 필립 오를레앙(Philppe d'Orleans) 공이 섭정한 시기로 1715년부터 1725년까 지의 기간이다. 중기는 루이 15 세가 직접 통치한 친 전시대로 1723년부터 1774년까지에 이르며, 말기는 루이 16세의 통치기간으로서 1774년부터 1789년까지 로 구분된다. 이 세 시기에 걸쳐서 로코코 문화가 발 전되어 왔다(Jeong, 2003). 로코코는 자갈을 뜻하는 로카 이유(rocaille)와 조개껍데기를 뜻하는 코키유(coquille) 의 합성어로 자갈이나 조개껍데기로 만든 곡선을 많 이 사용한 장식과다의 양식을 의미하는데, 프랑스를 중심으로 발달한 회화, 건축, 실내장식, 공예에 쓰인 장식양식의 명칭으로 18 세기의 우아하고 경쾌한 무 드의 문화사상을 말한다(Han, Seo, \& Lee, 2005).

\section{1) Rococo women's costumes}

로코코 중기시대의 여성복식에서의 특징은 고딕이 나 바로크스타일 실리주의적 쾌감을 추구하는 동시
에 장중한 중압감을 더욱 세련되게 하여 잔잔히 흐르 는 듯한 곡선, 섬세한 왕조풍의 우미한 여성적인 곡 선미를 의도적으로 강조하였다(Han et al., 2005). 또 한 물리, 화학의 발달로 염료의 질이 좋아지고, 염색방 법이나 염색기술이 발달하여 직물이나 의복의 색채 가 세련되었다. 특히 가슴을 깊이 파고 허리를 졸라 매어 둔부 부분을 펼침으로써 풍부하고 화려한 머리 장식품 등으로 우아한 정취를 드러내었다(Han, 2011). 여자 가운(gown)에는 줄무늬 · 꽃무늬가 있는 옷감이 많이 쓰였고, 조화나 코르사주(corsages)의 꽃장식과 주름장식을 하여 복식사상 가장 아름다운 예술작품 과 같은 의상을 만들어냈다(Shin, 2002). 특히 여자가 운의 종류와 명칭은 다양하지만, 기본구성방법은 언 더스커트와 오버 드레스로 이루어진 것으로 갈라진 오버드레스의 스커트 사이로 언더스커트가 보이게 되 어 있었다. 드레스 윗부분 중심에 $\mathrm{V}$ 자로 장식되었던 스토마커(stomacher)에는 위부터 아래까지 리본(bow) 장식이 매듭으로 장식되었는데 크기가 아래로 갈수 록 작아져서 마치 사다리처럼 보인다고 해서 에셀 (echelles)이라고 불리었다. 스커트는 파니에(paniers) 라는 스커트 버팀대를 이용해 양옆으로 부풀려 허리 를 가늘어 보이게 하였다. 네크라인은 U형태로 데콜 테(decollete)를 드러내었는데(Nam, 2009), 드레스가 깊게 파였을 경우 가슴이 드러나는 것을 피하기 위해 가슴에 레이스 장식을 하였는데, 이것은 모디스티 피 스(modesty-piece)로, 데콜타주(decolletage)를 가리는 쉬폰(chiffon) 스카프였다(Black \& Garland, 1980/2005). 소매의 형태는 팔꿈치길이의 팔꿈치까지 내려오는 반소매에 소매 끝에는 프릴(frill)이 달린 두세 겹의 레이스가 층층으로 장식된 앙가장트(engageantes)가 대표적인 소매였다(Shin, 2002).

\section{2) Rococo men's costumes}

다음 로코코(Rococo) 중기 시대의 남성 복식의 특 징을 살펴보면, 바로크 시대보다 허리는 더욱 들어가 고, 밑단 쪽으로 날렵하게 퍼진 좀 더 여성적인 형태 가 되었다. 스커트 자락을 넓히기 위해 옷자락 단에 고래수염 등을 삽입하기도 했고, 허리에 버튼을 달아 플레어 형태로 펼칠 수 있도록 하였다. 이런 스타일 을 입기 위해 남성들도 허리를 조이는 코르셋을 착용 하거나, 밑단으로 퍼지는 플레어 모양을 유지하기 위 
해 가는 뼈대를 코트 안에 넣어 이를 받쳐주었다고 한다(Kim, 1995b). 뒤쪽에는 일직선으로 벤트(vent: 상의의 등이나 겨드랑이, 스커트의 자락이나 커프스 등에 터놓은 부분)를 넣고 양 옆으로도 플리트가 있 는 벤트로 되어 있었다. 대개 칼라가 없었으나, 때로 는 폭이 좁은 스탠딩 칼라가 달려 있는 것도 있었다. 코트의 전면에는 목부터 옷 끝단까지 단추(button)가 달려 있었으나, 채우는 일은 거의 없었다(Black \& Garland, 1980/2005). 코트의 소매는 손목까지 오고 젖혀 진 커프스는 크고 넓은 모양이었다. 조끼는 이 시기에 가장 장식적인 역할을 하는 중요한 품목으로 종종 화 려하게 채색이 되었거나, 보석장식이 된 단추(button) 들이 일렬로 앞 중심에 달려 있었다(Kim, 1995b). 조끼 안에 입는 셔츠는 희고 얇은 아마포나 모슬린으로 만 들었다. 헐렁한 소매의 끝부분에는 레이스나 아마포 로 된 러플(ruffle)이 달려 있으며, 이 러플(ruffle)은 코트의 소매 위로 나오게 해서 입었다(Black \& Garland, 1980/2005). 셔츠 위에는 긴 천을 약간 넓은 밴 드 칼라모양으로 접어 목에 여러 번 두르고, 뒤에서 매어주거나 핀으로 고정시켜 앞 중심의 셔츠를 가리지 않게 스톡(stock) 타이를 맸다. 바지는 무릎 바로 아랫 길이로 바지부리의 밴드를 버클로 여미거나 리본 (bow)으로 매어 입었다(Shin, 2002).

\section{3) Common applied decorative elements}

로코코 중기의 남녀 복식의 특징을 살펴보면 전체 적으로 각각의 부착위치, 형태에 따라 프릴(frill), 셔 링(shirring), 자수(embroidery), 단추(button), 리본(bow) 등이 과장되고 화려하게 반복적으로 장식되어 있다. 또한 이 시대에는 레이스 사용이 화려함의 절정에 이 른 시기로서, 로코코 양식이 갖고 있는 특성과 레이 스가 가진 유연함과 부드러움, 섬세함이 서로 잘 부 합되어 발달하였다(Son, 2013). 외형적으로 입체감이 느껴지는 레이스 장식과 네크라인, 소매 단에 섬세하 고 가늘게 직조된 레이스 장식을 하여 의상을 더욱 화려하고 아름답게 하였다(Choo, 2012). 레이스는 여 성 복식에서 뿐만 아니라 남성 복식에서도 나타났는 데, 셔츠 소매 끝에 레이스 커프스(cuffs)나 러플이 장 식되었고, 와이셔츠 앞자락에 장식으로 쓰인 자보 (jabot)는 주름을 잡아 계단 모양으로 접어 조끼 사이 로 들여다보이게 입었다. 로코코 중기시대의 여성과
남성 복식의 특징과 장식적인 요소는 〈Table 1〉, 〈Table 2〉와 같다.

\section{Opera <La Serva Padrona> Analysis}

\section{Background of <La Serva Padrona $>$}

Opera 'La Serva Padrona(마님이 된 하녀)'는 1733 년 8 월 28일, 당시 나폴리의 왕 카를로 $\mathrm{VI}$ 세의 왕비인 엘리자베타 크리스티나(Elisabett aChristina)의 생일 축하연을 위해 성 바르톨로메오(St. Bartolomeo) 극장 에서 초연되었다(Heo, 1999).

이 작품이 발표된 18 세기 중기의 유럽사회는 왕족 과 귀족, 중산층인 유산계급의 시민계층과 무산계급 인 시민 등 총 네 가지 계급유형이 존재하는 계급사 회였다. 귀족과 시민은 물론 유산계급과 무산계급 간 의 계급을 초월한 결혼은 매우 드물고 어려웠다. 더 구나 당시의 신부들은 지참금을 가지고 결혼하는 풍 습이 있어 결혼 적령기 여자의 후견인들은 지참금에 크게 부담을 느끼고 있었다. 이러한 시대적 배경 속 에서 발표된 페르골레지(Pergolesi)의 'La Serva Padrona(마님이 된 하녀)'는 유산계급의 나이든 주인 우 베르토(Uberto)와 어려서부터 우베르토의 집에서 성 장한 하녀 세르피나(Serpina) 사이에서 일어난 결혼이 야기이다(Hur, 2009).

이야기의 배경은 18 세기 초 남부 이탈리아로 당시 귀족 중심 사회에서 상층 계급에 해당되는 우베르토 가 우유부단한 성격을 갖고 있고, 하층계급의 계략에 휘말리게 되는 것으로 그려진다. 이러한 스토리의 작 품이 당시에 인기를 끌 수 있었던 이유는 상층계급이 극중 스토리를 하층 계급들의 상층계급에 대한 도전 적인 의미로 해석하지 않고, 오락적인 희극물로만 생 각했기 때문이다. 그리고 이 오페라의 여주인공인 세 르피나는 ‘뱀(serpe)'이라는 이탈리아어에서 유래한 'Serpina'라는 이름에서 나타나듯이 성격은 까다롭고 영 악해서 부유한 노총각을 계략에 속이는데(Heo, 1999), 하층계급이 상층계급으로 신분상승을 할 수 있다는 상상에서나 가능한 일이 오페라에서는 이루어졌기 때문이다( $\mathrm{Li}, 2012)$.

\section{Synopsis of <La Serva Padrona $>$}

페르골레지의 'La Serva Padrona(마님이 된 하녀)' 
$<$ Table 1> Mid-18th century fashion

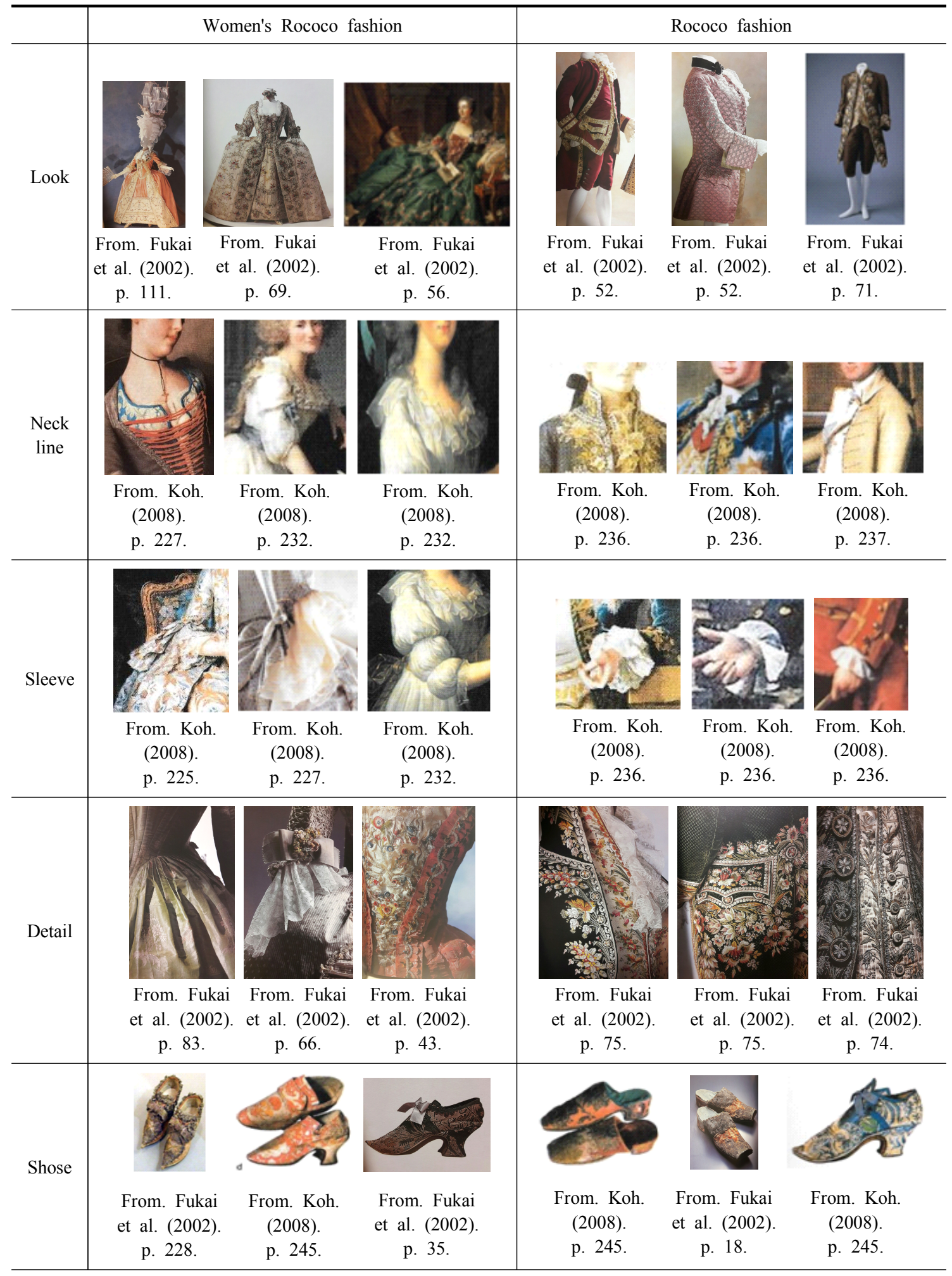


<Table 2> Rococo decoration elements

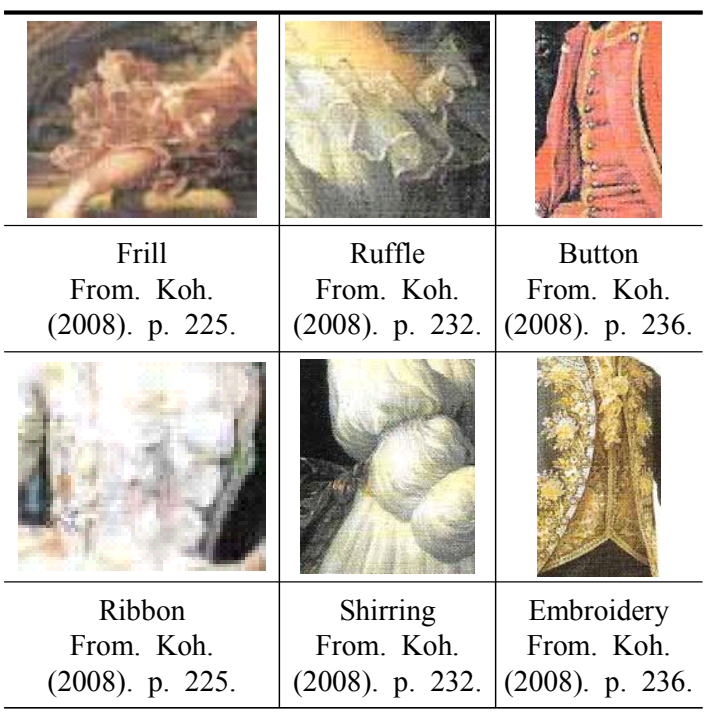

의 곡들은 레치타티보(recitativo: 대사를 말하듯이 노 래하는 창법), 아리아(aria: 주인공의 감정을 표현하는 독창부분), 이중창 형태로 음악구조가 구성되어 있으 며, 총 2 막으로 구성된다. 제 1 막은 약 22 분, 제 2 막은 약 28 분으로 총 연주시간은 약 50 분 정도가 된다. 노 래는 총 14 곡으로 구성되어 있는데 제 1 막에 7 곡, 제 2 막에 7곡이 배치되어 있으며, 극의 줄거리는 다음과 같다.

\section{1) Act I}

막이 올라가고 무대는, 돈은 많지만 독신으로 지내 는 게으른 노인인 우베르토의 침실이 나오는데, 때는 점심시간이다. 점심시간이 되었는데도 정해진 초콜릿 을 가져오지 않는 세르피나에게 불평하며 하인을 부 르는 방울을 울리자 그 소리를 듣고 들어온 것은 벙 어리 하인 베스포네(Vespone)이다. 여기에서 우베르토 가 아리아(aria)를 부르는데, 같은 동음을 반복함으로 써 우베르토의 조급해하는 심리를 묘사하고 있다. 우 베르토는 가까이에 있으면서도 아무 대답이 없는 세 르피나가 무엇을 하고 있는지 보고오라며 베스포네 를 보낸다. 세르피나는 베스포네에게 욕을 해대며 때 리기까지 한다. 제 2곡의 레치타티보(recitativo)에서 선율이 상행하면서 세르피나의 강한 신분상승적 욕 구를 나타내고 있다. 제 3곡 우베르토의 아리아에서 는 주인이면서도 위신이 서지 않는 속상함을 표현한
다. 화를 내기도 하고 베스포네에게 동의를 구하면서 세르피나에게 으름장을 놓는 다카포아리아(da capo aria: 아리아의 한 형식으로 노래가 더 기교적)로 노 래 부른다. 세르피나의 ㄲㄲㄲ이지 않는 반격에 우베르토 는 꼼짝하지 못한다. 이에 그 자리를 피하려고 외출 준비를 하지만 세르피나는 못나간다고 하며, 옷이나 갈아입으라고 명령조로 말하는데, 여기에서 하녀의 신분이지만 주인을 좌지우지하는 당당함과 영악함을 엿볼 수 있다. 이에 대조적으로 뻔뻔한 하녀를 야단 치지도 못하는 바보스러움이 노래에 잘 나타난다. 이 부분은 그 당시의 오페라 부파(Opera Buffa)에서 자 주 등장하는 권력자들의 우둔함과 어리석음, 그리고 우유부단함을 풍자하는 부분이라고 할 수 있다(Heo, 1999). 우베르토는 세르피나의 기에 눌려 쩔쩔매며 베스포네에게 못 생겼어도 좋으니 안주인으로 맞이 할 마음씨 착한 여자를 데려오라고 엄포를 놓는다. 그러자 세르피나는 우베르토에게 자신이 꼭 맞는 신 부감이니 자신을 이 집의 마님으로 삼으면 어떻겠냐 고 제안한다. 우베르토는 마음이 두근거리지만 넘어 가지 않겠다고 결심하는데, 세르피나는 우베르토에게 "말은 그렇게 하지만 당신의 눈은 나를 좋아한다"고 말하며 우베르토를 유혹한다.

\section{2) Act II}

우베르토의 응접실에서는 세르피나가 베스포네를 자기편으로 끌어들여 우베르토를 유혹할 계략을 세 운다. 세르피나는 베스포네에게 같은 편이 되었다고 하며, 대위의 군복을 입히고 더욱 적극적으로 우베르 토에게 질투심을 유발시켜서 유혹한다. 우베르토에게 자신이 괴상하고 난폭한 남자와 결혼하게 되었다고 말하고, 약혼자의 비위를 거스르면 그가 무슨 일을 저지를지도 모른다며 이별의 슬픔을 노래한다. 제 9 곡 아리아에서 세르피나는 아주 슬픈 어조로 처량하게 노래하며 매우 느리고 센티멘털하게 자신의 목적달성 을 위한 거짓 작별을 노래한다. 그러자 우베르토는 자신의 마음이 세르피나에게 끌려가고 있음을 느낀 다. 이때 세르피나는 미리 군인 템페스트(Tempest)로 변장시켜 놓은 베스포네를 우베르토 앞에 데리고 와 서 약혼자라 소개하고, 말 없는 대위의 뜻을 우베르 토에게 전한다. 세르피나는 대위가 우베르토에게 거 액의 지참금을 요구하며, 지참금을 내놓지 않으면 칼 
을 뽑아 난동을 부리겠다한다며 우베르토를 위협한 다. 그리고 만약 그것이 싫으면 세르피나를 부인으로 삼으라고 한다고 전한다. 세르피나의 계략은 성공하 여 우베르토는 대위 앞에서 그녀와의 결혼을 서약한 다. 희극 오페라의 끝맺음에 어울리는 유쾌한 2중창 으로 서로의 가슴속에 사랑의 소리가 울려퍼진다고 노래부르며 막을 내린다.

\section{Performance analysis}

\section{1) Analysis of theatrical costumes in overseas}

'La Serva Padrona(마님이 된 하녀)'는 해외에서 수 차례 공연되는 작품이다 보니 다양한 시도의 무대의 상을 볼 수 있으나, 유투브 시각자료 중에서 본 연구 자가 18 세기 의상을 가장 잘 나타낸 자료로 사료되는 두 작품과 18 세기의 로코코의 시대의상을 반영하지 않은 현대적 의상의 공연작품 중에서 한 작품을 선정 하여 분석하였다(Table 3).

1958년도에 안나 모포(Anna Moffo)가 세르피나역 을 공연한 영상자료에서는 18 세기 남자 패션에서 가
장 중요한 역할을 했던 백 위그(bag wig) 가발을 쓴 우베르토의 모습을 볼 수가 있다. 백 위그 가발은 18 세기에 유행했던 남자 가발의 한 형태로, 앞머리 쪽에 는 웨이브 컬이 있고, 뒤로 땋은 머리는 검정 리본을 장식한 정방형의 검정색 자루(bag) 안에 넣은 형태(Kim, $1995 b)$ 를 말하는데, 정장차림에서는 주로 이 가발을 사용하였다. 우베르토의 의상을 살펴보면 당시 유행 하던 레이스로 주름잡아 목 앞 중심에 늘어뜨리는 자 보(jabot)와 자수 장식의 웨이스트 코트(waist coat), 넓적한 커프스 소매가 있는 스탠드칼라의 코트를 착 용하고 있는 모습을 볼 수 있으며, 바지는 다리통이 꼭 끼고 무릎 바로 아랫길이의 브리치즈(breeches)를 착용한 모습을 볼 수 있다. 세르피나는 1770년대 이 후에 유행한 오버 드레스의 스커트 자락을 두 곳에서 위로 걷어 올려 뒷 중심과 양 옆에 커다란 퍼프(puff) 가 모두 세 개가 형성된 로브 아 라 폴로네에즈(Robe a la Polonaise)를 착용하였다. 이 시대 여성들이 가발 을 사용하지 않고 자신의 머리를 뒤로 빗어 넘겨 분 을 뿌린 단순한 퐁파두르 스타일(pompadour style)을 하였는데(Kim, 1995b), 이 영상의 세르피나 역시 퐁파

$<$ Table 3> Overseas performance

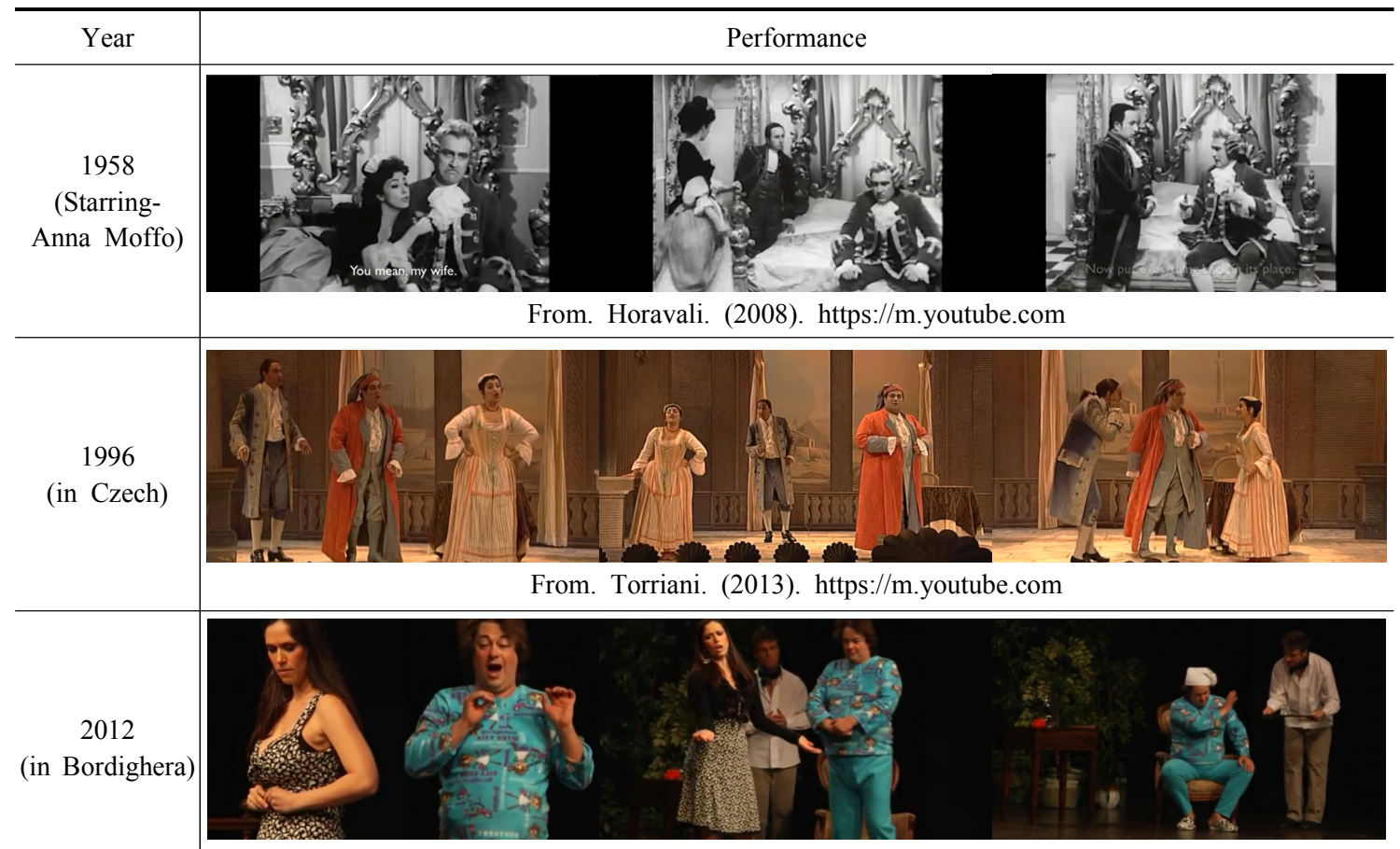

From. Claclawolverine. (2013). https://m.youtube.com 
두르 스타일(pompadour style)에 레이스로 만든 실내 용 캡(mob cap)을 쓴 모습을 볼 수 있다. 베스포네 의 상은 우베르토의 의상보다 장식이 덜 화려하지만, 우 베르토와 같은 자보와 스탠드칼라의 코트, 브리치즈 를 착용한 모습을 볼 수 있다. 신분을 암시하기 위해 우베르토는 가발을 착용하였으며, 베스포네는 가발을 착용하지 않은 것으로 역할과 신분을 상징하였음을 알 수 있다. 1996년 공연자료에서는 우베르토가 가발 대신 모자와 나이트가운을 착용하여 이제 막 기상한 아침 시간임을 나타내고 있다. 웨이스트 코트는 착용 하지 않고 자보 장식과 앞이 약간 파인 둥근 목둘레 로 칼라가 없는 코트를 착용하였다. 베스포네 의상도 마찬가지로 칼라가 없는 코트를 착용한 모습을 볼 수 있다. 세르피나의 의상에서는 드레스의 좌우를 확대한 드레스 형태인 로브 아 라 프랑세즈(Robe a la Francaise)를 착용하였으며, 깔끔한 업스타일에 실내용 캡 (mob cap)과 에이프런(apron)를 착용하여 당시 하녀 신분의 의상을 그대로 재현하였다. 18 세기의 로코코 의 시대의상을 전혀 반영하지 않고 현대적 의상으로 공연된 2012년도 영상자료를 보면, 캐릭터를 희극화 시키기 위해 유아적인 원숭이 그림이 프린트된 블루 색상 잠옷차림의 우베르토와 가슴골이 파인 기하학 적 프린트 원피스에 블랙 색상 볼레로 차림의 세르피 나를 볼 수 있다. 집안일을 제대로 하지 않는 현대의 파출부 모습을 표현하기 위해 에이프런은 착용하지 않고 액세서리로 큰 이어링을 착용하였다. 베스포네 목에는 스카프를 두르고, 흰 남방과 면바지로 집안일 의 허드렛일을 하는 직업을 표현하였다.

이와 같이 같은 작품일지라도 무대의상과 무대연 출에 따라 극의 분위기와 시각 효과는 전혀 달라지며, 각각의 공연마다 특징을 부여하는 효과도 달라짐을 알 수 있었다.

\section{2) Analysis of theatrical costumes in Korea}

국내에서는 'La Serva Padrona(마님이 된 하녀)'가 많이 알려진 작품이 아니다 보니 해외에서 공연한 횟 수에 비해 국내에서 공연한 횟수는 상대적으로 매우 적다. 온라인 기사를 검색한 결과, 2010년 4월 25일 작곡가 페르골레지의 탄생 300 주년 기념으로 백운아 트홀에서 초연된 바 있으며(“Culture News", 2010), 2013년에는 삼성아트홀에서 3월 14일부터 4월 27일

까지 오페라로서는 보기 드물게 장기 공연된 바 있다 (Fig. 1). 2014년에는 더 하우스 콘서트 공연팀이 전국 공연 투어 작품 중 〈마님이 된 하녀〉가 가장 높은 관 객 호응도를 받아 정읍사 예술회관과 인천 복합문화 공간 아트홀 소풍에서 공연을 했다. 2015년에는 인천 서구시설관리공단 문화회관(Moon, 2015)과 강릉에서 공연(Lee, 2015)을 했고, 2016년에는 함양문화예술회 관(Choi, 2016)과 영주문화예술회관에서 '더하우스' 공 연팀 주관에 의해 꾸준히 공연되어졌다(Fig. 2).

국내의 'La Serva Padrona(마님이 된 하녀)' 무대 의상은 2010년부터 2016년 사이 공연된 자료들 중에 서 더하우스 공연팀이 순회 공연하는 무대의상과 삼 성아트홀에서 공연된 무대의상 외에는 더 이상 자료를 찾기 어려운 문제점이 있었다. 따라서 국내의 무대의 상 분석은 두 공연팀의 무대의상으로만 비교 분석하 였는데, 2013년 삼성아트홀에서 공연된 의상을 살펴 보면 로코코시대 의상의 스타일을 고증한 스타일로 자보(jabot)와 자수 장식의 웨이스트 코트(waist Coat) 브리치즈(breeches)를 착용한 우베르토역의 모습을 볼 수 있었다. 그러나 우베르토의 의상에서 원색적인 레드 색상의 베스트에 민트 그린색의 골드 자수는 전 체적으로 색상의 통일감을 주지 못했고, 세르피나 의 상 역시 퍼플색과 플라워 프린트 무늬의 조합은 로브 아 라 폴로네에즈(Robe a la Polonaise)를 제대로 고 증하지 못한 아쉬움을 주었다. 더하우스 공연팀의 무 대의상은 현대적인 블랙 메이드복에 화이트 에이프

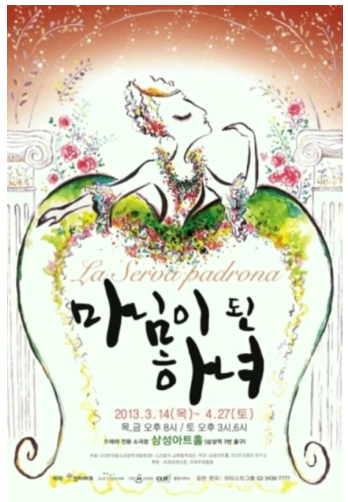

<Fig. 1> 2013 performance

From. Hoya. (2013). https://m.blog.naver.com

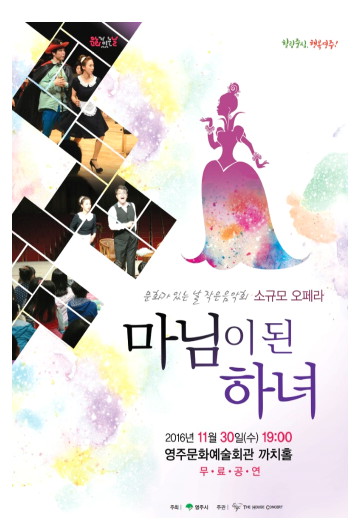

<Fig. 2> 2016 performance From. Anjeong. (2016). https://m.blog.naver.com 
$<$ Table 4> Korea performance

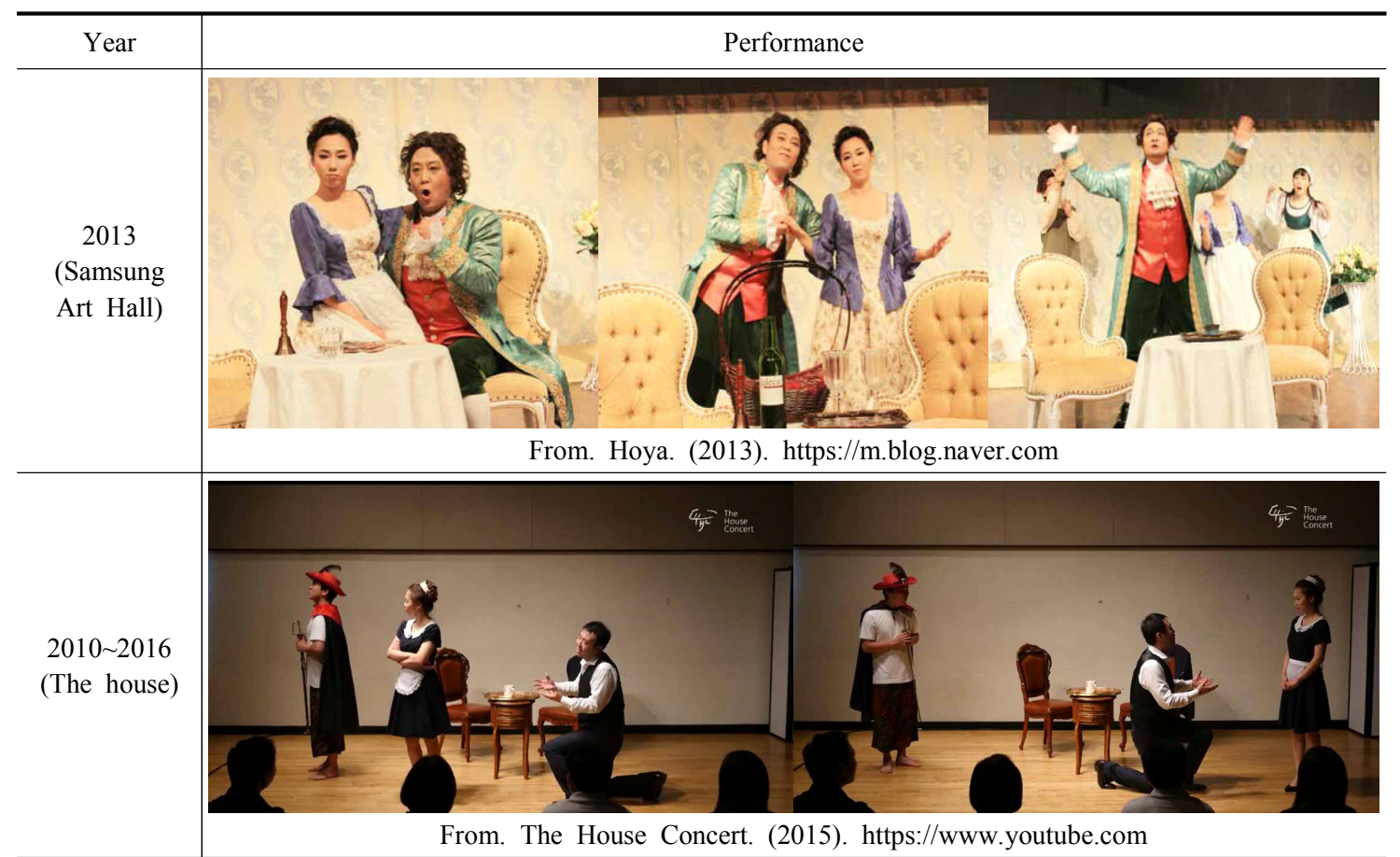

런과 헤어캡이 세르피나 의상으로 연출되었고, 우베 르토는 일반 흰색 셔츠와 블랙 베스트, 블랙 바지가 착용되어졌다. 베스포네는 티셔츠차림에 바지차림으 로 입고 등장하다 2막에서 템테스트로 변장할 때는 우스꽝스러운 모자와 망토를 착용하였다. 현대적인 의상으로 공연하여 관객에게 친숙한 분위기를 전달 하고자 하는 의도는 좋았으나, La Serva Padrona(마 님이 된 하녀)가 단순 코믹 오페라가 아니라, 페르골 레지가 작곡한 로코코 시대의 배경을 통해 작품의 의 의는 분명 관객에게 전달되어져야 함에도 불구하고, 이를 무대의상을 통해 표현하지 못한 아쉬움을 주었 다(Table 4).

\section{Result of Stage Costume}

오페라 무대의상은 공연을 위한 특수한 목적을 가 진 특수의상으로서 표현성에 치중한다. 오페라 가수 가 그 역할을 하는데 있어서 움직이는 몸짓이나 행동 을 도와 그 기능을 수행하게 하는 것으로서 극의 무 대, 연출, 연기의 묘사에 도움을 주도록 해야 한다 (Kim, 1995a). 또한 극의 추상적 분위기를 무대 위에
서 시각적으로 구체화함으로써 극의 주제나 사상과 같은 비실체적인 부분들을 암시해주며, 극중 인물이 사는 시대와 장소, 인물의 사회적 위치, 현재의 환경, 연령, 성별, 직업, 성격 심지어는 인물의 감정 상태까 지도 반영하여 표현할 수 있다(Cho, 1999). 또한 비극 오페라에서 무대의상은 수수하고 위엄 있게 표현하 며, 희극 오페라에서는 광대장비와 해학적인 의상 등 으로 공연유형을 상징적으로 표현해줌으로써 작품의 성격을 나타낸다(Kim, 1995a). 시각적인 부분에서도 오페라가수의 외면적인 부분과 내면적인 부분을 모 두 드러내 보이면서 관객에게 미적인 만족감을 주도 록 해야 한다. 무대 위에서 의상을 입고 있는 배우는 무대 위에 살아 움직이는 섬유작품으로서 미학적인 면을 고려하여 의상의 선, 형태, 색채, 질감들을 조화 롭게 결합하여 그 시대의 보편성을 갖는 미로 표현해 야 한다(Kim, 1995a). 특히, 무대의상은 신체의 편안함 과 동작을 고려한 의복구성이 요구되어지는데, 움직 임이 편하고 호흡에 지장이 없도록 착용감을 배려해 야 한다. 또한 공연 도중 의상을 신속하게 갈아입을 수 있도록 솔기와 특수지퍼를 이용하여 기술적인 면 에서도 디자이너의 세심한 요구가 필요하다. 
무대의상은 관객에게 효과적인 전달을 위해서 선, 색채, 소재 요소들과 더불어 마지막으로 중요하게 고 려해야만 하는 사항이 무대 미술과의 연관성 및 공연 하는 극장의 공간과 크기, 관객과의 거리감이다(Cho, 1999). 오페라는 음악과 의상, 무대예술의 공간성이 서 로 어울려 진행되었을 때 종합예술로서의 가치가 커 진다.

본 장에서는 2015년 10월, 실제 공연 대본을 통해 주인공의 성격과 심리묘사를 어떻게 음악적인 효과 를 나타내었는지를 관찰해보고, 연출가의 의도와 컨 셉에 맞게 연구하였다. 무대의상은 로코코 중기 시대 의 장식적 요소들을 현대적으로 재해석하였으며, 앞 서 살펴본 바와 같이 18 세기 로코코 중기 복식의 화 려함은 실루엣이나 옷감, 색채에서 표현되기보다 과 다한 장식요소들을 옷에 부착시켜서 장식 미에 치중 한 화려함이었다고 할 수 있다. 또한 장식적 요소를 강하게 지녔으며, 여성스러운 장식요소를 통하여 감 각적으로 표현한 것이 특징이었다. 따라서 본 연구의 무대의상은 로코코 중기시대에서 사용되었던 가장 특 징적인 디테일들을 러플(ruffle), 프릴(frill), 셔링(shirring), 자수(embroidery), 단추(button), 리본(bow) 장 식을 현대의상으로 재해석 및 적용하여 오페라 ' $\mathrm{La}$ Serva Padrona(마님이 된 하녀)'의 등장인물인 우베르 토, 세르피나, 베스포네에게 극의 구성과 음악의 특성 에 맞게 무대의상 디자인 및 제작하였다. 각 등장인 물에게 선정된 색상은 색채연상 이미지 자료를 참고 하였으며 각 등장인물에 따라 인물의 성격, 개성, 신 분, 계급에 맞는 무대의상을 디자인함에 그 방법은 〈Table 5〉와 같다. 이를 바탕으로 실제 공연한 무대의 상은 〈Fig. 3〉과 같다.

\section{Uberto}

이 작품에서 우베르토는 나이 많고 게으른 부자주 인의 모습을 표현하기 위해 굵직한 베이스(bass) 음성 으로 노래한다. 극중 노래하는 음성 톤을 시각화하기 위해 의상 컬러의 선정은 무거운 그레이 컬러와 블랙 컬러를 주 색상으로 표현하였고, 우베르토 의상의 디 자인적인 특징은 로코코 중기시대의 남성 복식인 웨 이스트 코트(waist coat)를 조끼 스타일로 디자인하여 단추를 장식하였다. 로코코 중기시대에 남자들이 입 었던 브리치즈(breeches) 스타일은 무릎길이에 다리
통이 꼭 끼는 형태로 활동성이 떨어짐을 고려하여 현 대적인 남자복식의 상징적인 의미가 되는 스트레이트 (straight) 바지 디자인으로 제작하여 착용감의 편리성 을 주었다. 셔츠는 로코코 시대의 스탠드 칼라(stand Callar) 형태는 목이 불편함을 고려하여 넥 뒷부분은 스탠드 칼라로 하고, 넥 앞 부분은 타이의 착용을 편 하게 하기 위해 윙 칼라(wing collar)로 새 날개처럼 옷깃의 앞면이 부드럽게 젖혀진 스타일로 디자인하 여 제작하였다. 우베르토 의상의 소재 선택은 상류계 급을 표현하기 위해 고가의 태즈메이니아 울(Tasmania wool)을 사용하였다. 태즈메이니아 울은 매우 섬세 하고 부드러운 소재로 표면촉감과 광택이 우아한 소 재로서 조끼와 바지에서 사용하였다. 셔츠는 실크 소 재를 사용하였고, 로코코 중기 시대에 남성들이 목에 매었던 자보(jabot)를 심플하게 현대적으로 재해석하 여 사선 스트라이프의 문양이 들어간 타이 형태로 제 작하여 포인트를 살렸다(Table 6).

\section{Serpina}

여주인공 세르피나의 성격을 분석하여 보면 성공 지향적인 인물로서 신분상승의 적극성에서 비롯되는 뻔뻔스러움과 영악함을 엿볼 수 있다. 따라서 세르피 나의 교활한 이미지의 색채이미지는 레드 색상으로 표현하였다. 의상의 디자인적인 특징은 원피스 형태의 드레스로 로코코 중기시대의 장식요소인 셔링을 바 스트에 표현하였다. 또한 로코코 중기시대에는 에이 프런(apron)이 화려한 실크에 수를 놓고, 가장자리는 금사 레이스를 두른 것부터 은빛 레이스로 만든 우아 한 것에 이르기까지 다양한 종류가 있었는데, 이 시대 에는 에이프런이 중요한 자리에 갈 때도 착용할 정도 로 여성들에게 매우 인기를 끌었던 장신구였다(Payne, 1965/1997). 따라서 세르피나의 에이프런은 집안일도 하면서 장신구 역할로서 에이프런의 헴 라인(hemline) 과 헤어 캡에도 로코코 중기 시대의 장식요소인 프릴 장식을 하였고, 의상의 디테일적인 선은 곡선을 적용 하여 로코코 시대 양식인 로카이유(rocaille) 장식을 표현하고자 하였다. 소재 선택은 하녀 신분에게 어울 리는 저가의 면(cotton) 소재로 원피스 형태의 드레스 를 만들었으며, 로코코 시대의 가장 상징적인 소재라 고 할 수 있는 레이스(lace) 소재로 볼레로를 디자인 및 제작하였다. 또한 세르피나가 드레스 위에 착용한 
$<$ Table 5> Process of the design development







<Fig. 3> From. Lee. (2016). https://www.youtube.com

$<$ Table 6> Stage costume production of Uberto

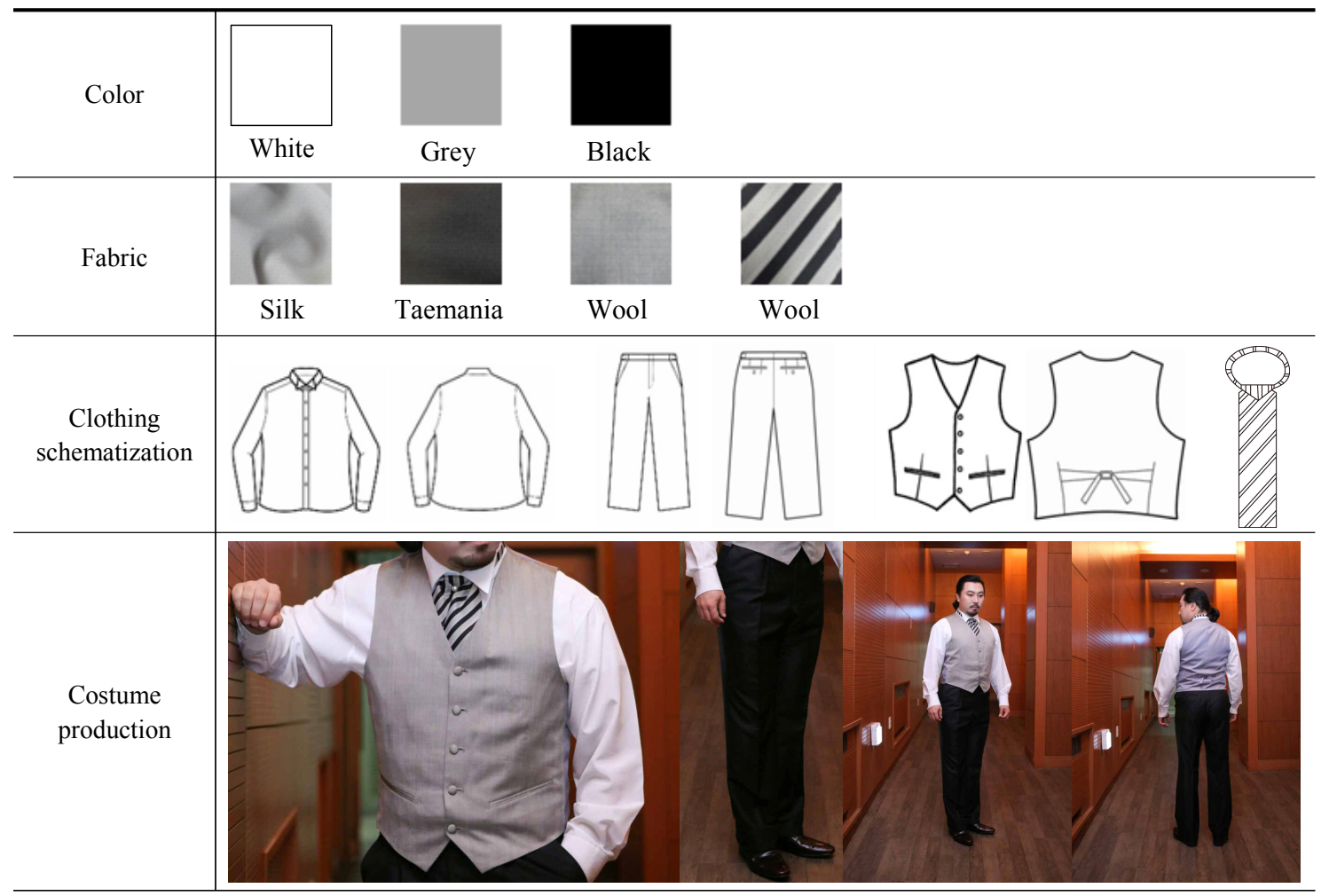

에이프런은 에이프런의 소재로는 잘 사용하지 않는 미카도(mikado) 소재를 사용함으로써 일을 잘하는 이 미지보다는 주인의 말을 잘 듣지 않고, 하녀 신분임 에도 일을 제대로 수행하지 않는 이미지를 표현하고 자 하였다(Table 7).

\section{Vespone}

베스포네는 대사가 없는 벙어리역이라 개성을 나 타내는 캐릭터 분석이 어려워 하인 신분에 맞는 의상 디자인으로 진행하게 되었다. 1 막에서 베스포네의 하
인의상은 세르피나와 공범으로서 우베르토를 속이는 데 일조하는 인물이자 세르피나와 같은 하인 신분임 을 표현하기 위하여 유사한 색상을 선택하였다. 의복 의 아이템 구성은 18 세기 하층계급의 대표적인 스타 일인 조끼와 보우타이, 와이셔츠, 바지로 구성하였다 (Table 8).

2막에서 베스포네가 군인 템페스트(Tempest)로 변 장할 때는 위엄과 무게감을 나타내기 위해 블랙 색상 으로, 기백과 힘을 과시하기 위해 자수 부분은 골드 색상으로 매치하였다. 코트의 디자인적인 특징은 18 
$<$ Table 7> Stage costume production of Serpina

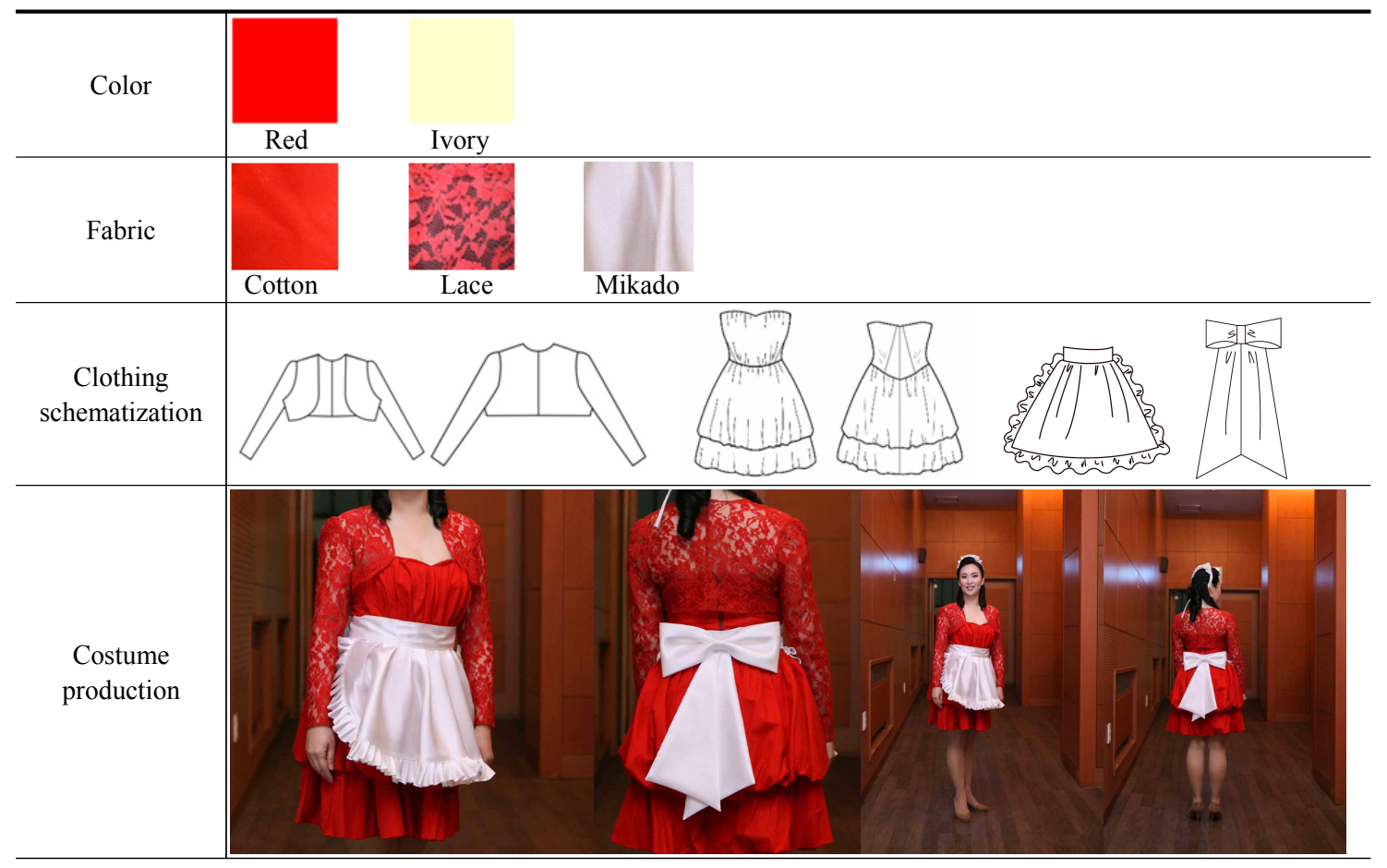

$<$ Table 8> Stage costume production of Vespone




$<$ Table 9> Stage costume production of tempest

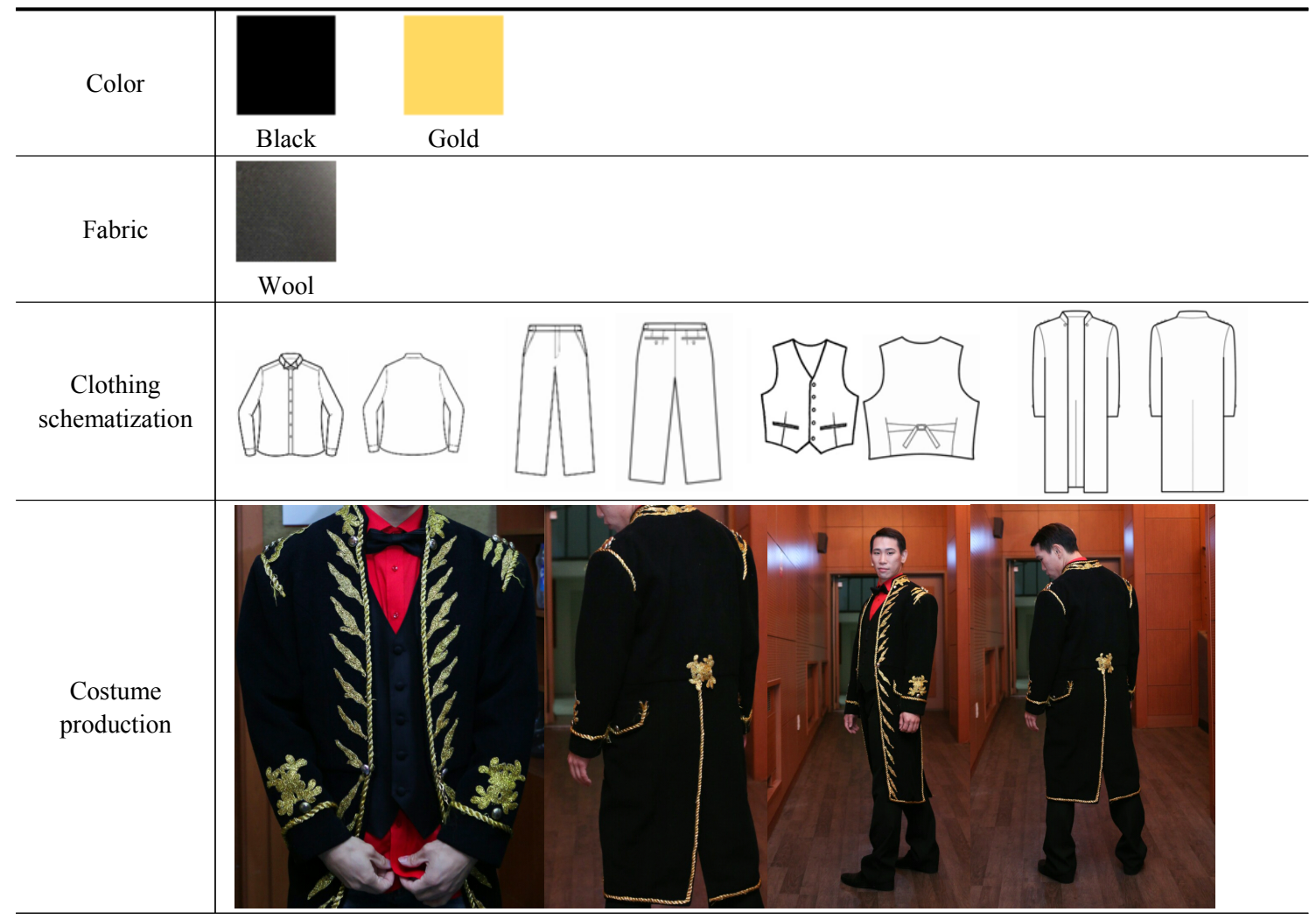

세기 중기 남성 복식의 코트에서 볼 수 있는 장식요 소인 자수와 브레이드(Braid)를 소매 끝단과 어깨, 코 트 여밈 부분에 장식 효과를 주었고, 소재는 울 소재 를 사용하여 제작하였다(Table 9).

\section{Conclusion}

오페라는 세계적으로 500 년 이상의 역사를 가지고 있으며, 종합예술로서 국가, 사회, 문화적으로 많은 영향력을 미칠 수 있는 장르중 하나이다. 그 안에 연 극, 성악, 합창, 발레 등이 총체적으로 어우러져 있어, 한 나라의 문화적인 척도가 된다고 할 만큼 종합예술 로서 높은 가치가 있고 그 나라의 문화와 예술이 종 합적으로 표출된다. 그럼에도 불구하고 국내에서는 자연스럽게 많은 대중이 향유하기엔 어려운 공연으 로 인식하고 있다. 따라서 본 연구는 국내 논문연구 에서는 발표되지 않았지만 보다 오페라가 대중에게 쉽게 다가갈 수 있도록 희극 오페라의 효시라 할 수
있는 페르골레지(Pergolesi)의 'La Serva Padrona(마님 이 된 하녀)'의 무대의상을 현대적인 해석에 따라 작 품의 특징과 내용을 고찰하였으며, 다음과 같은 결론을 얻었다.

'La Serva Padrona(마님이 된 하녀)' 작품은 대규 모의 서정적 오페라와는 달리 등장인물이 3 명에 이르 고, 악기 편성 또한 소규모로 이루어졌다. 당시의 시대 적 경향인 상류층 계급을 풍자하는 모습이 등장하며, 주제가 서민적이고 사회적 관습의 모순이 희극적으 로 묘사되었다. 2 막의 종결부인 피날레에서는 중창을 삽입시켜 활기에 넘치는 앙상블로 희극 오페라의 특징 을 살린 작품으로서 이탈리아식 가벼운 오페라가 전 유 럽에 보급되는데 큰 역할을 하였으며 오페라부파 (opera buffa)라는 희극 오페라 장르가 발전되는 계기 를 마련하여 음악역사상 중요한 작품이었음을 알 수 있었다. 따라서 페르골레지(Pergolesi)의 'La Serva Padrona(마님이 된 하녀)' 무대의상 연구는 소비자의 지적 수준 향상을 위해 다양한 오페라 분야에 대한 
무대의상을 현대화한 것으로서 의미가 있다.

로코코(Rococo) 중기 시대 의상의 복식 연구 고찰 을 통해 작품의 등장인물별, 역할별 무대의상의 특징 을 현대적으로 재해석하여 제작한 결과는 다음과 같 다. 첫째, 과거 로코코(Rococo) 중기 시대의 남자 복 식은 다양한 방법으로 장식미를 표현하였으며, 이를 현대적으로 무대의상에 적용하는 것은, 남자 의상의 새로운 스타일을 제시하고, 무대의상의 무한한 발전 을 가능하게 하였다. 둘째, 남자 주인공은 나이 많고 게으른 부자 주인의 모습을 표현하기 위해 굵직한 베 이스(bass) 음성으로 노래하는데, 극중 노래하는 음성 톤을 시각화하는 의상 컬러의 선정은 인물묘사의 핵 심요소로서 대상인물의 캐릭터를 표현하고, 무대의상 을 현대화하는데 큰 역할을 차지하였다. 셋째, 로코코 (Rococo) 중기 시대의 로카이유(rocaille) 장식의 곡선 을 응용하여 여자 주인공에게는 하녀역할을 상징화 할 수 있도록 헤어캡과 에이프런(apron)에 프릴(frill) 장식을 시도하였는데, 이는 당시의 시대상인 계급주 의와 신분에 따른 직업의 구분을 표현할 수 있었고, 또한 현대적인 여성적 아름다움을 표현하였다. 넷째, 18 세기 복식의 특징적인 요소만 응용하여 현대적인 소재로 제작함으로써 제작비의 부담을 더는 경제적 인 효과와 착용감을 편하게 하는 효과를 기대할 수 있었다. 다섯째, 과거 복식사에서의 형태와 기법의 도 입은 다양한 측면에서 복식 표현의 주제가 될 수 있 었고, 이러한 주제를 통하여 과거와 현대와의 조화가 이루어져 시대감각에 맞는 극의 주제를 명확히 전달 하는 데에 도움이 되었다.

오페라 무대의상은 상품으로서 판매를 목적으로 하 는 일반 의상과 달리 무대 공연을 목적으로 하는 의 상이다. 이에 따라 유럽의 음악 역사상 중요한 작품 이었던 'La Serva Padrona(마님이 된 하녀)'의 무대의 상을 현대화시킨 시도는 극의 스토리 전개와 인물의 성격, 개성, 신분, 계급, 심리적 변화 등을 표현해주는 이미지 전달 역할과 함께 주제와 내용을 상징적으로 암시하는 데에 고전 오페라에 대한 관객의 이해도와 친숙도를 높이도록 긍정적인 역할을 기대할 수 있었 다. 또한 로코코(Rococo) 시대는 밝고 세련된 귀족 취 향, 유희와 쾌락을 추구하는 사치스러우면서도 장식 적 요소가 극에 달했던 특징을 가지고 있었다. 이러 한 로코코(Rococo) 중기 시대의 장식적 요소였던 러 플(ruffle), 프릴(frill), 셔링(shirring), 자수(embroidery), 단추(button), 리본(bow) 장식을 현대의상으로 재해석 및 적용하여 제시함으로써 무대의상 디자인 범위를 확장에 기여했다.

앞으로도 고전 오페라에 대한 무대의상 디자인은 시대적인 거리감을 좁히기 위해 현대적 사고에 의한 재조명 작업이 꾸준하게 필요할 것이다. 또한 최근 안목이 높아진 일반 관객을 만족시킬 수 있도록 무대 의상의 소재와 색상, 디테일 부분에 있어서도 새로운 시각과 발상의 전환이 되는 디자인 개발이 필요하며, 나아가 국제화 시대에 맞게 수준 높은 문화 사업으로 서 경쟁력 있고 부가가치의 창출에도 도움이 되는 무 대의상에 대한 연구가 지속적으로 이루어지길 기대 하는 바이다.

\section{References}

Anjeong. (2016, November 22). 11월 문화가 있는 날 작은 음악회 소규모 오페라 '마님이 된 하녀' [November cultural day, mini-concert small scale opera 'La Serva Padrona'] [Blog Post]. Retrieved May 15, 2017, from https://m.blog.naver.com/shin $5964 / 220867587166$

Black, J. A., \& Garland, M. (2005). A history of fashion (G. S. Yoon, Trans.). Seoul: Gandhiseowon. (Original work published 1980)

Byun, Z.-H. (2005). A study on the modernization of stage costume of opera 'Faust \} _ { \lrcorner } \text { . Unpublished mas- } ter's thesis, Gachon University, Gyeonggi-do, Korea.

Cho, E.-H. (1999). The design process of stage costume and drama costume. Unpublished master's thesis, Konkuk University, Seoul, Korea.

Choi, E. I. (2007). A study on stage costumes of the opera 〈Turandot $\rangle$. Unpublished master's thesis, Ewha Womans University, Seoul, Korea.

Choi, I. S. (2016, May 21). 함안 하우스콘서트 소규 모 오페라 '마님이 된 하녀' 열려 [Haman House Concert Small opened]. Asia news agency, Retrieved May 15, 2017, from http://m.anewsa.com/ article_sub3.php?number $=1017604$

Choo, S. A. (2012). A study on the contemporary fa- 
shion design adapting lace. Unpublished master's thesis, Hongik University, Seoul, Korea.

Claclawolverine. (2013, October 26). Pergolesi - La Serva Padrona 1996 [Video file]. Retrieved May 15, 2017, from https://m.youtube.com/watch?v= 0QRml6yGZL0\&feature=youtu.be

Crane, D. (2004). Fashion and its social agendas: Class, gender, and identity in clothing (M. S. Seo, Trans.). Paju: Hangilsa. (Original work published 2000).

Culture News. (2010, April 16). Naeil News. Retrieved May 15, 2017, from http://news.naver.com/main/ read.nhn mode $=$ LSD $\&$ mid $=$ sec $\&$ sid $1=001 \&$ oid $=0$ $86 \&$ aid $=0002003425$

Fukai, A., Suoh, T., Iwagami, M., Koga, R., \& Nii, R. (2002). Fashion: A history from the 18th to the 20th century. Koln: Taschen.

Han, S. J., Seo, O. G., \& Lee, M. J. (2005). 서양복식 문화사 [Western costume history]. Seoul: Yehagsa.

Han, W. Y. (2011). A study on the characteristics of make-up and color appeared in the Rococo portraits. Unpublished master's thesis, Hongik University, Seoul, Korea.

Heo, J. (1999). A study on the comique opera of $G$. B. Pergolesi's 〈La Serva Padrona〉. Unpublished master's thesis, Ewha Womans University, Seoul, Korea.

Horavali. (2008, June 15). "Stizzoso, mio stizzoso", Anna Moffo, 1958 [Video file]. Retrieved May 15, 2017, from https://m.youtube.com/watch?feature=youtu.be $\& v=$ PysUIPOFvGc

Hoya. (2013, March 12). [오페라 마님이 된 하녀] 화 이트데이에 만나는 깜직하고 사랑스러운 오페라 [Opera La Serva Padrona: Pretty and lovely Opera meet on White day] [Blog Post]. Retrieved May 15, 2017, from https://m.blog.naver.com/kimri333/ 40183470570

Hur, E. W. (2009). A study on the characters and their musical descriptions in the 18th century Opera Buffa. Unpublished doctoral dissertation, Dong- duk Women's University, Seoul, Korea.

Jeong, H. S. (2003). 서양복식문화사 [A history of fashion]. Paju: Gyomoonsa.

Kang, J.-E. (2005). The research of stage costumes of the Opera Aida: Based on 1980s' and 1990' opera performances. Unpublished master's thesis, Keimyung University, Daegu, Korea.

Kim, H. S. (1995a). The visual effect of opera costume and stage lighting: Rigoletto. Unpublished master's thesis, Sookmyung Women's University, Seoul, Korea.

Kim, H. S. (1995b). 무대의상 디자인의 세계 [The world of theatre costume design]. Seoul: Koryowon.

Kim, I.-M. (2002). A study on the modern designs of the opera stage costumes. Unpublished master's thesis, Dongduk Women's University, Seoul, Korea.

Kim, J. (2002). A study on the pattern construction of Rococo style. Unpublished master's thesis, Duksung Women's University, Seoul, Korea.

Kim, J.-H. (2005). A historical and analytical study on the development of Korea opera. Unpublished doctoral dissertation, Keimyung University, Daegu, Korea.

Kim, Y. J. (1998). 복식미학의 이해 [Understanding costume aesthetics]. Seoul: Kyungchunsa.

Koh, A.-R. (2008). 서양의 복식문화와 역사 [A history of fashion]. Paju: Gyomoonsa.

Lee, A. (2016, February 5). 이안연출 오페라 '마님이 된 하녀' 01 [An Lee directed opera 'La Serva Padrona' 01] [Video file]. Retrieved May 15, 2017, from https://www.youtube.com/watch? $\mathrm{v}=\mathrm{n}$ 3ONJMFd3xA

Lee, H. N. (2015, June 30). 오페라 '마님이 된 하녀' 내달 3일 강릉 공연 [Opera 'La Serva Padrona' gangleung performance]. Gangleung-ilbo, Retrieved May 15, 2017, from http://m.kwnews.co.kr/nview. asp?s=601\&aid $=215062900150$

Lee, S.-J. (2004). A study about stage costumes of the opera "Tosca". Unpublished master's thesis, 
Chung-Ang University, Seoul, Korea.

Lee, S.-Y. (2007). The study on stage costumes for opera, the magic flute with clothing constructions. Unpublished master's thesis, Chung-Ang University, Seoul, Korea.

Li, Y. (2012). A study of G. B. Pergolesi's La Serva Padrona. Unpublished master's thesis, Chungnam National University, Daejeon, Korea.

Moon, H. K. (2015, May 5). 오페라 '마님이 된 하녀' 코믹 재해석 14 일 서구시설공단문화회관서 만나 요 [Reinterpret of the comic opera 'La Serva Padrona']. Incheon-ilbo, Retrieved May 15, 2017 , from http://m.incheonilbo.com/?mod=news\&act=article View\&idxno $=579261$

Nam, J. H. (2009). A study of the fashion design influenced by the rococo women's costume: Centered on work production by pleats. Unpublished master's thesis, Dankook University, Gyeonggido, Korea.

Shin, S. O. (2002). A history of costume in the west. Seoul: Soohaksa.

Son, D.-R. (2013). A study on jewelry design with the harmony of the crystal and lace. Unpublished master's thesis, Kookmin University, Seoul, Korea.
The House Concert (2015, August 4). 제451회 하우 스콘서트 - G.B.페르골레시 오페라 마님이 된 하 녀': 박경태(Bass), 황상미(Soprano), 천도협(Baritone) [The 451th House Concert: G.B. Pergolesi Opera 'La Serva Padrona'] [Video file]. Retrieved May 15, 2017, from https://www.youtube.com/ watch? $\mathrm{v}=\mathrm{gLrz} 8 \_$bvSHw\&feature $=$youtu.be

Torriani, C. (2013, June 9). Carlo Torriani sings: LA SERVA PADRONA by Giovanni Battista Pergolesi - Complete Opera [Video file]. Retrieved May 15, 2017, from https://m.youtube.com/watch? $\mathrm{v}=$ srRpZDd6pj4\&feature=youtu.be

Yang, S. H. (1984). La Serva padrona of G.B. Pergolesi: An Opera Buffa study through La Serva padrona. Unpublished master's thesis, Sungshin Women's University, Seoul, Korea.

Yoo, M.-I. (2011). A study on the analysis of stage costume design on Opera 'La Traviata': With emphasis on stage costumes of 'Violeta' and 'Alfredo'. The Treatise on The Plastic Media, 14(3), 115-126.

Yoo, M.-I. (2013). A study on stage costume for Opera 'AIDA'. The Treatise on The Plastic Media, 16(2), 121-128. 